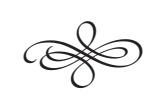

\title{
Clamoring for Liberty: Alehouse Noise and the Political Shoemaker
}

\author{
Peter Denney \\ Griffith University
}

In I794, as the Pitt government was cracking down on the popular reform movement, an anonymous Loyalist pamphleteer published a brief history of one of the political clubs and societies that had become radicalized in Britain in the wake of the French Revolution. ${ }^{1}$ The focus of the account was the apparent vulgarity, or incivility, of the club, as exemplified by the derogatory toasts and rancorous conversations of its members. But the club had not always been disreputable. According to the pamphleteer, it began as a "convivial society" of great "respectability," and only after the French Revolution did members become "politically mad," wishing to "subvert" the established order. With this shift, the status of the members also changed, as gentlemen left the society and artisans took their place. Intriguingly, such downward mobility was registered in acoustic terms, with intemperate, aggressive, plebeian discussion replacing a model of polite discourse based on equanimity, moderation, and courtesy. ${ }^{2}$ The current chairman was a tailor, whose "overbearing" speeches violated basic standards of decorum. Similarly, the leading spokesman was a shoemaker, a follower of Tom Paine with a misguided belief in the power of his own eloquence, as if supposing that the conversations of the workshop provided adequate preparation for engaging in political debate. As the Loyalist pamphleteer opined:

Eighteenth-Century Life

Volume 4I, Number 2, April 2017 DOI IO.I215/0098260I-384I408

Copyright 2017 by Duke University Press

105 


\section{Eighteenth-Century Life}

Your infatuated admirers call you the Prince of Orators, and declare you are the most eloquent speaker among your diabolical associates! . . But you are an incorrigible dunce, and a contemptible blockhead, for you have neither head to think nor a tongue to speak. I shall not enter into an altercation with this son of Crispin, who wants every requisite to form the Gentleman and the Scholar, but conclude by an excellent admonition-

"Ne sutor ultra crepidam,"

or, in the language of fair translation, "Cobler, go home and stick to thy last."3

Boasting a classical pedigree (from Pliny), this proverb, "Cobler, go home and stick to thy last," had great currency in polite culture and toyed with the popular myth of the shoemaker intellectual. If only to mock the concept of plebeian intellectual activity, it recognized that shoemakers were, indeed, renowned for making judgments on political issues that were considered the exclusive preserve of the formally educated. To arrive at the same conclusion, Elizabeth Montagu contrasted radicals like Painewhose "principles" were then being "sounded" by the rebellious colliers she employed at her estate in North Yorkshire-with an alternative popular myth, that of the "honest Cobler," sincere, clownish, and content in his station. ${ }^{4}$ Yet Montagu had in mind, here, a rather domesticated shoemaker compared to the one found in popular culture, for in chapbooks and ballads, the attributes of the honest cobbler were double-edged, signifying not only happiness, but also bluntness, irreverence, and an independence of polite opinion.

Drawing on a selection of these popular cultural sources, especially ballads and chapbooks, this essay examines the process by which, during the eighteenth century, the shoemaker came to be depicted as the champion of a distinctively plebeian republic, forged in the alehouse through noisy rituals of masculine sociability. This was in stark contrast to the growing tendency in polite culture, evident from around the $178 \mathrm{os}$, to propagate an ideal of quiet artisanal domesticity. Opposing such an image, several popular radicals in the era of the French Revolution resurrected an old tradition of shoemaker lore to show how the ethos of noisy alehouse sociability could further plebeian claims to citizenship, representing irreverence as an indispensable component of civic virtue.

It is worth noting, here, that both polite and popular writers often conflated shoemakers with cobblers, as Montagu did in the example above. But, in a technical sense, cobblers and shoemakers performed quite differ- 
ent forms of work. Whereas shoemakers made shoes, cobblers only repaired them. And there were also cordwainers, who sometimes identified simply as shoemakers and sometimes regarded themselves as superior artisans due to their high level of independence. ${ }^{5}$ Either way, cobblers possessed a lower status than shoemakers, with their relative lack of respectability frequently depicted in terms of a fondness for noise. And this explains why the shoemaker poet, James Woodhouse, took great offense when many critics dismissed him as an upstart cobbler, implying that he was a bungling versifier when he was, in fact, an accomplished cordwainer as well as a published author. ${ }^{6}$ Nevertheless, the distinction between cobblers and cordwainers was not particularly rigid in terminology or in practice during the eighteenth century, and shoemakers came to refer to a broad occupational category. At the same time, as we shall see, political shoemakers were almost always represented as cobblers with an appetite for noisy, exuberant, impulsive activity. This clearly either emphasized their low social status, to denigrate their political or intellectual aspirations, or suggested that such elite interests were legitimate pursuits for all artisans.

As Eric Hobsbawm and Joan Wallach Scott argued in their classic and quite brilliant essay, shoemakers had a well-deserved reputation for being popular politicians and philosophers throughout the eighteenth century. ${ }^{7}$ Noted for their independence of thought, they regularly assumed responsibility for guarding plebeian morality and mobilizing the local populace against injustice. Accordingly, their workshops became hubs of sociability and debate. Coupled with their relatively high levels of literacy, this placed them at the center of the political and intellectual life of their communities well before the rise of organized radicalism made them spokesmen for their class. In this sense, shoemakers saw themselves as political actors, patriots who exercised a plebeian version of the public virtue that, in the theory of classical republicanism, was limited to gentlemen of property.

Early in the century, in fact, it was not uncommon for classical republican writers to represent the shoemaker as an embodiment of the liberty, bravery, and independence of laboring people. ${ }^{8}$ These qualities were often associated with forms of social and political noise, singing and talking at work when times were good, but engaging in vociferous protest when rulers were corrupt. In Cato's Letters, published in the I720s, for example, the vices of the Whig oligarchy were depicted as giving rise to vigorous, voluble protest, and this expression of plebeian disaffection was interpreted as a patriotic affirmation of liberty. Because "every cobbler," wrote Cato, “can judge, 
as well as a statesman, whether he can sit peaceably in his stall," he was a legitimate censurer of the state and its statesmen. ${ }^{9}$ Of course, in its elite version, the classical republican tradition was reactionary rather than radical, and it accommodated the grievances of laboring people only to deny them full membership in the polity. Characteristically, the proverbial independence of the shoemaker was identified with naïveté rather than with the active demonstration of public virtue, justifying as well as limiting his political agency. ${ }^{10}$ In Oliver Goldsmith's The Citizen of the World (1760-6I), for instance, an "honest cobler" traverses the worlds of polite and plebeian culture, appearing as a philosopher, a storyteller, and, finally, a popular politician. He is ultimately, though, an ambivalent figure, inane and impudent, ridiculed and celebrated, as evidenced by the patrician persona he adopts at a carnivalesque local election: "I must own I could not avoid being pleased to see all ranks of people on this occasion, levelled into an equality. ... I could perceive a cobler with a levee at his door, and an haberdasher giving audience from behind his counter." ${ }^{11}$ Coexisting with the urbane condescension of this satire was an urban version of merry England, with its comic depiction of laboring people as spirited and affable if benighted and hapless folk. Nevertheless, like the authors of Cato's Letters, Goldsmith perceived the suppression of boisterous plebeian behavior to be the result of political corruption, which, by coercing freeborn Englishmen into "silence," turned them into "slaves" who were no longer able to "murmur without reproach" (2:I42). In relation to the policing of the populace, this reflected a permissive strain of the classical republican tradition, demonstrated by its aversion to a permanent standing army and other organs of monarchical or executive power. ${ }^{12}$ Despite defending hierarchical social relations, such writers thus made it possible to represent the noisy shoemaker, however comic, as an embodiment of English liberty.

This, at least, was the conclusion that Thomas Spence came to in the I79os. In his radical magazine, Pigs' Meat, Spence appealed to the irreverent instincts of a plebeian readership, combining "low" forms of popular parody with "high" modes of political and social criticism. Of the various elite writings he reproduced, many were taken from the classical republican tradition, including both this passage from The Citizen of the World and the depiction of the political shoemaker in Cato's Letters. ${ }^{13}$ With the subdivision of labor and desocialization of work proceeding apace in the late eighteenth century, this tradition spoke to the ingrained prejudices, customary expectations, and current grievances of literate artisans. Of particular appeal 
were attitudes such as the idealization of independence, the distrust of an exploitative financial elite, and the hostility to modes of work-discipline that separated the spheres of labor and leisure. Consequently, as classical republicanism mutated into a variety of radical populism, it became the ideology "par excellence" of the gifted plebeian autodidact. ${ }^{14}$ There was, of course, much irony that an elite body of political thought, which treated plebeian intellectual activity with disdain, was assimilated into a profoundly irreverent popular culture, giving it a degree of respectability at the very moment that it was being attacked by polite moral reformers for causing impiety, idleness, and a potentially subversive solidarity. Nevertheless, Spence articulated an important artisanal value by insisting, again quoting "Cato," that liberty required a man "to call his tongue his own," a notion as relevant to defending popular culture as to establishing modern democracy (I:3).

Similar imagery pervaded chapbooks and street ballads, which comprised the bulk of popular literature. Chapbooks, in particular, played a crucial role in nourishing and extending literacy in plebeian communities. ${ }^{15}$ Because these popular media, however, were often communicated by wordof-mouth - read aloud in workshops, say, or sung in public alehouses - they were not restricted to literate members of the laboring classes. ${ }^{16}$ At any rate, despite enormous variety at this social level, reading abilities were hardly negligible and almost certainly improving, especially among urban artisans. ${ }^{17}$ Whatever the case, written texts frequently became occasions for conviviality, making print media serve the demands of a resiliently oral culture and, by implication, strengthening communal bonds. In consequence, spreading literacy and expanding print culture amplified the sound of human voices, with plebeian reading regularly being a noisy, public affair attended by reciting, singing, declaiming, and other oral modes of expression. ${ }^{18}$ The convivial function of chapbooks was further reinforced by the texts themselves, for not only did they translate oral forms into print, but their main purpose was to provide amusement, and their major theme was merriment. ${ }^{19}$ Even ballads that were explicitly political in content were subordinated to the sociable environments in which they were sung. In addition, songs, riddles, and stories often made "merry England" a bass note of their social protest. While ballads were not organically plebeian, they adapted "high" modes of poetry — satire and comedy, epic and pastoral — to the traditional tastes of laboring people. ${ }^{20}$ And the same was true of chapbooks. ${ }^{21}$ Whether fictional or topical, popular literature was thus incorporated into a plebeian value system, even as its meanings were modified in 
myriad ways. As such, printed texts like ballads and chapbooks helped to buttress the symbolic rituals and customary expectations that were orally enacted by laborers and militantly defended against encroachers.

Shoemakers figured prominently in this popular literary tradition, arguably on account of their distinctive culture. Among artisans, it has been asserted, only weavers possessed a stronger sense of craft identity. ${ }^{22}$ In a range of texts dating back to the Renaissance, shoemakers were frequently associated with ritualized leisure practices, as if to represent them as custodians of a genuinely plebeian holiday calendar. ${ }^{23}$ Throughout the eighteenth century, moreover, they commemorated the "holyday" of their patron saint, Crispin, with an annual procession and feast. Similarly, in a custom that one polite reporter thought should be either "sobered" or made "obsolete," journeymen met together every first Monday in March when, partly at the expense of their masters, they drank, sang, and toasted by candlelight until the early hours of the morning. ${ }^{24}$ These annual rites constituted an urban equivalent of the harvest home by serving to bolster solidarity within artisanal groups and to validate the small workshop as a locus of production, sociability, and lore. In the process, they reinforced feelings of craft pride, which, for shoemakers, were based, among other things, on the indispensability of their trade to rich and poor alike (Hobsbawm and Scott, 96). Just as important, though, were the quotidian rituals that reproduced the ideals of the workshop in the alehouse, thereby integrating the day-to-day rhythms of labor and leisure..$^{25}$

In both workshops and alehouses, artisans felt free to voice their grievances, discuss politics, and sing subversive or, simply, escapist songs. According to E. P. Thompson, who wrote perceptively if briefly about the acoustic symbolism of plebeian behavior, this sense of liberty was bound up with the control they exercised over their work and leisure. ${ }^{26}$ As a result, artisans regarded oral performances as vital aspects of their independence. This was especially true for shoemakers. Because their work was neither demanding nor deafening, shoemakers' workshops were conducive to conviviality and conversation, often becoming "social centers" for laboring men (Hobsbawm and Scott, Io4). As members of one of the poorest and leastskilled trades, however, shoemakers were early reduced to the dishonorable situation of working at home. Since this reflected their self-employed status, this actually enhanced their independence. But symbolically, working in close proximity to the domestic sphere compromised the masculine identity upon which their independence was based, severing penurious 


\section{Eighteenth-Century Life}

shoemakers from public spaces of sociability and political debate. To compensate for this, as Anna Clark has argued, they created a deeply misogynistic culture that promoted conviviality in the alehouse, while condoning domestic violence. ${ }^{27}$ Notwithstanding this dark side of artisanal culture, the oral performances of male shoemakers were not just opposed to the interests of plebeian women, for noise-making of all sorts also acted to stress their independence from the moral, social, and economic demands of the polite classes.

Shoemaker culture was affected, in interesting ways, by popular literature. Notably, the self-employed status of shoemakers was depicted as producing, rather than social isolation, an independence that was fostered by the convivial pleasure that attended their trade. For example, in a sixteenth-century chapbook, written by Thomas Deloney and adapted and republished in multiple editions in the eighteenth century, their songs were represented as integrating their labor and leisure, confirming the honor of their craft:

Of all the Crafts, the Gentle-Craft is best,

Their pleasant Songs make Labour seem like Rest;

In Mirth and Comfort all the Year they live,

And unto Strangers oft Relief they give. ${ }^{28}$

Praising the nobility and heroism of the patron saints, Crispin and Crispianus, the full title of this chapbook, The Shoemaker's Glory: or, The Princely History of the Gentle Craft, contained a patriotic subtext, which informed many aspects of shoemaker lore. A similar style of patriotism, of course, had been represented by Shakespeare in Henry $\mathrm{V}$, when the king invoked St. Crispin's Day on the eve of battle in order to erase social distinctions in his army, imagined as a community of shoemakers, or "band of brothers," whose solidarity, bravery, and fighting ability made them ideal soldiers. ${ }^{29}$ From at least the late seventeenth century, shoemaker culture fostered a sense of national identity based on military prowess, applauding Protestant heroes like William of Orange, and articulating an overtly masculine vision of Britain. ${ }^{30}$ Indeed, this muscular patriotism was the source of craft pride in a political ballad of I710, The Gentle Craft's Complaint. Blaming the decay of this "noble ancient Trade" on high taxation and the exportation of leather, the ballad eulogized the "Honour of Shoe-makers" - their readiness, as "brave Boys by free Consent," to form combinations and petition Parliament-in the same language as it lauded 
Queen Anne and her statesmen for exhibiting the public virtue needed to redress their grievances. ${ }^{31}$ Predictably, too, the manly qualities that goaded these "brave Shoe-makers" to defend their trade also incited the chauvinistic drinking rituals - the "merry" singing, toasting, and huzzahing - that celebrated the craft's victory as a vindication of English liberty.

The description of shoemakers in this ballad as "brave," "jolly," and "honest" was typical of the presence in popular literature of the comic mode and its variant, the myth of merry England. Artisans did not need to ascribe to the reality of either a comic image of the "honest mechanic" or a harmonious view of English society to recognize that such street ballads were effective vehicles for making their own idea of independence consonant with an authoritative account of political liberty. For shoemakers, moreover, songs added a convivial and, therefore, public significance to work that had become increasingly privatized. As one ballad asserted:

A Cobler there was, and he liv'd in a stall,

Which serv'd him for Kitchen, for Parlour, and Hall;

No coin in his pocket, no care in his pate,

No ambition had he, nor no duns at his gate.

Contented he was, and he thought himself happy,

If at night he could purchase a jug of good nappy,

O then he would whistle and sing too most sweet,

Saying, just to a hair I have made both ends meet. ${ }^{32}$

If this image of the "honest cobbler," content in his poverty and his labor, reassured polite moral reformers like Elizabeth Montagu, it undoubtedly had a different resonance for shoemakers themselves. For contentment, here, derives from earning enough wages to subordinate work to the pleasures of drink and song-to possess the independence, that is, to join something of a plebeian republic. The point was made most curiously in The History of the King and the Cobler, an enormously popular chapbook in which a self-styled "honest Cobler," after insisting that he means "no harm," proclaims:

I'll laugh when I sit in my stall,

And merrily will sing,

That I with my poor last and awl, Am fellow with a King. ${ }^{33}$ 
Although the comic tone of this chapbook ensures that its protagonist appears naïve and, hence, innocuous, it is typical of much popular literature in blurring into the carnivalesque. As a kind of irreverent, plebeian version of Bolingbroke's "patriot king," Henry VIII is cast in the role of the populist hero, walking the streets of London incognito until he ends up, in a quasi-egalitarian fantasy, laughing, singing, and drinking with a feisty cobbler. Clearly, this "world-turned-upside-down" was a mental universe away from any sort of political radicalism. But it was equally distant from the sobriety, work discipline, and quiet domesticity that, in the polite imagination, were becoming the key criteria of plebeian respectability.

Until the midcentury, conservative critics would probably have regarded The History of the King and the Cobler with wry amusement, proof of the vulgarity, but also the unthreatening stupidity, of its plebeian readers. By the 1780 , however, when at least one of its many editions was published, it must have seemed potentially subversive, a stepping stone to the radical populism of the alehouse, as it had been articulated by supporters of John Wilkes and, later, of the American Revolution. For in a trend Wilkes initiated, popular cultural forms, along with the oral performances they sustained, were being deployed by radical activists to persuade plebeians to accept their plans for parliamentary reform, if mostly under the guise of aristocratic or, at least, middle-class political leadership. ${ }^{34}$ As one balladeer asserted, by inciting the laughter of the crowd, "Wilkes's rough music" had driven away the enemies of "old England," the opponents of singing, merriment, and liberty. ${ }^{35}$ Similarly, in an anti-Wilkesite poem, published in $\mathrm{i764}$, Theophilus Hogarth ridiculed a shoemaker politician and orator called Crispin for inciting the "noise" of the "ragged" crowd, who responded to the "music of his tongue" by huzzahing and applauding their "patriot-hero." ${ }^{36}$ Wilkes's followers regarded the movement as permitting them a degree of leisure and unruliness, with performances of Cato taking place in alehouses and radical ballads being sung and heard in all manner of social spaces. ${ }^{37}$ With the number of radical ballads proliferating in subsequent decades, it was not surprising that Elizabeth Montagu would observe in 1779 that it had become "as usual" for artisans "to talk treason as to hum a tune or whistle" (Letters, ed. Blunt, 2:75). In short, the singing and whistling of the "honest cobbler," formerly signs of contentment and inanity, were redefined as potentially seditious vocalizations of disaffection. Rather than suggesting liberty, they indicated, to quote Montagu 


\section{Eighteenth-Century Life}

again, the "licentious spirit of the times, the aversion to all law, rule, and discipline" (2:76). For shoemakers, this amounted to a repudiation of their independence, undermining their right to discuss politics, sing songs, or just talk out of earshot of their polite superiors.

At the same time, the popularization of classical republican thought by pro-American radicals made it possible for artisans to conceive their independence as a source of public virtue. From this perspective, the convivial culture of the alehouse became an expression of their citizenship. Accordingly, denying their customary grievances or suppressing their noisy pastimes began to be perceived as a form of political oppression. This was evident in a pamphlet of $\mathrm{I} 775$, The Cobler's Politics. Anti-papist, anticlerical, and deeply anti-authoritarian, a "free-born English" cobbler rails against a ministry who "Call ev'ry hard Grievance a Rebel's Pretence / Which will ruin our Trade, and drive Liberty hence." ${ }^{38}$ In an argument that encompassed numerous issues, from introducing a permanent standing army to prohibiting free speech, the assumption, here, was that a corrupt government defined liberty as coterminous with the deferential silence of the people:

They hold with Scotch Politics; foolish and weak;

Are silent, but when they for Tyranny speak.

And sure as my Hammer doth pelt hard on Leather,

Eighteen of their Heads shou'd be knock'd hard together. (I3)

To counter this view, the author used the genre of the popular dialogue to depict a conversation in a "Country Alehouse" between a "Blacksmith" and a "Cobler," the latter "being much the greater Politician" (iii). Making the case for parliamentary reform, he affirmed the patriotic spirit of shoemakers and linked their oral customs to a concept of liberty that resonated with the culture of artisanal sociability. Still, an urbane distance from these "Billingsgate" patriots was maintained. For, while polite radical pamphleteers sought to invite laboring people to denounce the ministry, they did not intend to invest these plebeian politicians with the self-determining capability of the disinterested citizen.

Yet artisans may have offered a different reading, for they could now claim that the songs and conversations that symbolized their independenceespecially their control over the rhythms of labor and leisure-also constituted them as legitimate political actors, devoted to the public good. Suddenly, to talk politics in the alehouse was to perform the part of the citizen. 
Even the comic idioms that were meant to inhibit their political agency could be used to confer respectability on their irreverent forms of protest and diversion, licensing the often carnivalesque resistance to polite moral norms. This propensity for laboring people to appropriate a comic version of polite political rhetoric had already raised anxieties in some quarters. In I763, for example, John Brown held comic literature responsible for provoking unruly displays of popular defiance, leading to the deposition of local magistrates..$^{39}$ Apparently, comedy had been abandoned to the crowd, advancing rather than belittling its political aspirations.

Thus, the formerly benign representation of the model artisan as a noisy shoemaker came to seem increasingly threatening to polite society, more menacing than merry. In particular, the songs and conversations that had long been regarded as valuable or tolerable aspects of plebeian culture were reinterpreted as signs of licentiousness rather than liberty. ${ }^{40} \mathrm{At}$ the height of the Wilkes affair, for example, John Wesley challenged the populist assumption that "every Englishman is a politician" as inclined "to talk politics as to breathe," and pilloried the belief that "every cobbler, tinker, porter, and hackney-coachman" was able to "point out every blunder of this or that minister."41 Of laborers, he added, quoting the famous proverb, "Ne sutor ultra crepidam! Let them mind to their own work," and he justified this on the grounds that to form an accurate judgment of political affairs required "more time than common tradesman can spare"; for this reason, to encourage laborers to pass judgment on affairs of state did immense "mischief" ( $(42-43){ }^{42}$ It was not surprising that the founder of Methodism should propound the view that laboring people did not have the leisure needed to engage meaningfully in political activity. The influence of evangelicalism on polite society during this period reinforced the belief that work discipline provided the only effective antidote to what was perceived as the ungodly, irrational, and dissolute effects of collective plebeian leisure, from drunken singing to bawdy jesting. In The Task in I785, for instance, William Cowper glowingly depicted the deserving poor as "industrious, modest, quiet, neat," whereas work-shy artisans were characterized by "fiddle screams" and disputes, as "smith, cobbler, joiner" retired to the alehouse to become "all loud alike, / All learned, and all drunk." 43 Similarly, another poet, James Hurdis, redefined the center of the plebeian community as the church rather than the alehouse, a "prudent" place of assembly where laborers could listen in silence to a sermon instead of 
attending the "haunts obscene" where cobblers "swill'd" cups of "barbarous intoxication." ${ }^{44}$ In short, because laboring people were now thought as likely to talk politics as to swill pints and sing crude songs during their intervals of leisure, the model artisan was reconstructed as a quiet, obedient, and industrious individual.

Such a shift in the polite perception of the model artisan intensified in the I79os, when an insistence on the virtue of quietness became a staple of Loyalist propaganda. As in the Cheap Repository tracts by Hannah More, much of this propaganda took the form of stories and songs intended to dissuade laboring people from participating in unproductive collective activity, especially political protest. ${ }^{45}$ Many of More's tracts drew on a well-known tradition of moralizing about the difference between industry and idleness, as depicted by William Hogarth in his famous series on the opposing fates of two apprentices, one lazy and the other diligent. ${ }^{46}$ And it was no coincidence that, in I795, More published a tale entitled The Two Shoemakers, which contrasted the advantages of a life of quietness, of work and domesticity, with the disastrous consequences of a preference for noisy, public leisure. On the one hand, Jack Brown, the idle shoemaker, was constantly distracted from his labor by the sound of sociability emanating from outside the workshop. "At every noise he heard in the street, down went the work. . . . If a blind fiddler, a ballad singer, a mountebank, a dancing bear, or a drum, were heard at a distance-out ran Jack-nothing could stop him, and not a stitch more could he be prevailed on to do that day." 4 Sound, in this instance, was threatening, because it penetrated even private spaces, paying no respect to physical boundaries. But the workshop itself was also a venue for producing social noise, and this caused much grief to James Stock, the "modest, industrious, pious" shoemaker. "James went on in a regular course of industry, . . . but there were many things in the family which he greatly disapproved." Of particular concern was that "some of the journeymen used to swear, drink, and sing very licentious songs" (IO). Predictably enough, James ended up as a master shoemaker, while Jack ended his life in the parish workhouse, after an inevitable stint in prison. In this manner, The Two Shoemakers exemplified how Loyalist propaganda attacked the value system of laboring people, as expressed and transmitted by oral media such as ballads and chapbooks. ${ }^{48}$ In the process of disavowing noisy social behavior, these tracts accorded no positive value to irreverence or even merriment, qualities that constituted central thematic and stylistic elements in popular culture. Across the spectrum of Loyalist writ- 


\section{Eighteenth-Century Life}

ings, the model artisan was imagined as a quiet figure, possessing a mind averse to collective political agitation.

By contrast, some popular radicals deployed the image of the noisy shoemaker to harness the customary beliefs and expectations of the poor to the revolutionary cause. Far from persuading artisans to renounce an atavistic popular culture for a formal rational republicanism, these writers portrayed the irreverence of their plebeian audience as an expression of their virtuous independence, a quality vital to liberty. ${ }^{49} \mathrm{~A}$ case in point was the story "The Honest Cobler," included by Daniel Isaac Eaton in Politics for the People, a periodical dedicated to translating radical political thought into an accessible, popular idiom:

Not many years ago an honest cobler, who had a vote for a certain borough, being accosted by a certain Court candidate for his vote, declared he would reserve it to the last; when being again applied to name his terms; why then, says honest Crispin, "kiss my a-se are mine." The polite Courtier, offended at such indelicacy, offered any sum, \&c. but still Crispin was resolved, and "kiss my a-se or no vote from me," was the resolution. The fate of the election depended on his single voice. The polite Courtier complied, and the honest cobler voted for t'other side, as his conscience directed; declaring that a scoundrel that could be mean enough to "kiss his a-se," was unworthy of a seat in Parliament. May the nation never be without such like honest Crispins; and may all such, or other bribing scoundrels, be alike served at every election, and then the House will be without knaves, and the people without grievances! ${ }^{50}$

The image of the "honest cobler" enabled radical polemicists to reinterpret a distinctively plebeian idea of independence as a form of public virtue, the attribute of the rebellious artisan no less than of the rational citizen. In the process, the assumption that laboring people enjoyed the right to make noise was extended to encompass the notion that they possessed, also, the duty to assert their voices in the defense of liberty. And this duty was represented as being entirely consistent with the irreverence that pervaded popular songs and chapbooks, filled, as they were, with coarse humor, parody, and antiauthoritarian sentiment.

The brilliant radical satirist John Wolcot (alias Peter Pindar), revealingly, was inspired to compare the suppression of the labor privileges of journeymen shoemakers to the repression of the civil liberties of the nation as a whole. ${ }^{51}$ "Clos'd be your mouths, or dread the jail or thong," Pindar sarcastically wrote in response to the present climate of surveillance, 
before predicting that "black-fac'd, damn'd Oppression ... / Shall howling fly before the curse of Men." ${ }^{52}$ And it was equally illuminating that Thomas Spence included this ode, satirically entitled "Resignation," as an appendix to one of his radical prophecies, for Spence played a crucial role in establishing a style of popular political debate that encompassed singing, talking, and arguing, in addition to silent reading and calm conversation. ${ }^{53}$ Indeed, the radical utopia Spence hoped to bring into being was to be accompanied not only by the sound of trumpets, but by the whole earth breaking "forth into singing." 54

By the I79os, arguably the most influential proponents of popular radicalism were suspicious of noisy collective activity, not least because they stressed the rational, deliberative, orderly aspects of political participation. Nevertheless, this emphasis on respectability coexisted with an attempt to represent radical political activity as compatible with the customary culture of the crowd. As we have seen, one revealing figure in this radicalized popular culture was the noisy political shoemaker, whose fondness for singing, conviviality, and irreverence produced enlightenment no less than enjoyment, generating rather than weakening his commitment to reform.

\section{Notes}

I would like to thank John Barrell, Kevin Gilmartin, and Annie Janowitz for their encouraging comments on an earlier version of this essay, and the ARC Centre of Excellence for the History of Emotions for helping to fund much of the research.

I. See Peter Clark, British Clubs and Societies, 1580-I800: The Origins of an Associational World (Oxford: Oxford Univ., 2000), 96.

2. For this model of polite conversation, see Jon Mee, Conversable World: Literature, Contention, and Community, I762-I830 (Oxford: Oxford Univ., 20II), 39-67.

3. Will's Coffee-House (1794), BL 648.c.26 (85).

4. Mrs. Montagu, "Queen of the Blues": Her Letters and Friendships from $I 762$ to I800, ed. Reginald Blunt, 2 vols. (London: Constable, 1923), 2:289, 306.

5. Giorgio Riello, A Foot in the Past: Consumers, Producers, and Footwear in the Long Eighteenth Century (Oxford: Oxford Univ., 2006), 170, and Joan Lane, Apprenticeship in England, I600-I9I4 (London: Univ. College London, I996), I22.

6. See Bridget Keegan, "Cobbling Verse: Shoemaker Poets of the Long Eighteenth Century," The Eighteenth Century: Theory and Interpretation 42 (200I): 195-217, especially 210-II.

7. E. J. Hobsbawm and Joan Wallach Scott, "Political Shoemakers," Past and Present 89 (1980): 86-II4, especially 88-89, 92-93. 


\section{Eighteenth-Century Life}

8. Equally, however, the image of the shoemaker as the ideal artisan was also used by advocates of passive obedience, as in Francis Atterbury, The Voice of the People, No Voice of God (London: [John Baker], I710), 5 .

9. John Trenchard and Thomas Gordon, Cato's Letters (I720-24), ed. Ronald Hamowy, 2 vols. (Indianapolis: Liberty Fund, I995), r:Io3.

Io. See, for example, The Curate and Cobler (London: C. Warburton, I754), $30-32$.

II. Oliver Goldsmith, The Citizen of the World (I760-6r), 2 vols. (London: J. Newbery, I762), 2:189.

I2. See Francis M. Dodsworth, “'Civic' Police and the Condition of Liberty: The Rationality of Governance in Eighteenth-Century England," Social History 29 (2004): 199-216.

13. Pigs' Meat; or, Lessons for the Swinish Multitude (1794), 3rd ed., 2 vols. (London: T. Spence, I795), 1:274-76, 2:3-8.

I4. W. D. Rubinstein, Elites and the Wealthy in Modern British History: Essays in Social and Economic History (Brighton: Harvester, 1987), 344, 353-6o.

I5. Victor E. Neuburg, Popular Literature: A History and Guide (Harmondsworth: Penguin, 1977), I07.

I6. Adam Fox, Oral and Literate Culture in England, I500-I700 (Oxford: Oxford Univ., 2000), 36-50.

I7. For plebeian literacy rates and abilities during this period, see Lawrence Stone, "Literacy and Education in England, I640-1900," Past and Present 42 (I969): 69-I39, especially I02-I2; R. S. Schofield, "Dimensions of Illiteracy, I750-I850," Explorations in Economic History Io (1973): 437-54; and David Cressy, "Literacy in Context: Meaning and Measurement in Early Modern England," in Consumption and the World of Goods, ed. John Brewer and Ann Bermingham (London: Routledge, I993), 305-I9.

I8. David Vincent, Literacy and Popular Culture: England 1750-19I4 (Cambridge: Cambridge Univ., I989), 20I-02.

I9. See, for example, the selection provided by John Ashton, Chapbooks of the Eighteenth Century (1882; London: Skoob, 1990); see also Barry Reay, Popular Cultures in England, I550-I750 (Harlow: Longman, I998), 63.

20. Robin Ganev, Songs of Protest, Songs of Love: Popular Ballads in EighteenthCentury Britain (Manchester: Manchester Univ., 2009), 31-34.

2I. Lance Bertelsen, "Popular Entertainment and Instruction, Literary and Dramatic: Chapbooks, Advice Books, Almanacs, Ballads, Farces, Pantomimes, Prints, and Shows," in The Cambridge History of English Literature, $1660-1780$, ed. John Richetti (Cambridge: Cambridge Univ., 2005), 6I-86, especially 63-67.

22. Peter Burke, Popular Culture in Early Modern Europe (1978; Aldershot: Wildwood House, I988), 36-39. See also Hobsbawm and Scott, "Political Shoemakers," 95-IO3.

23. Alison A. Chapman, "Whose Saint Crispin's Day Is It?: Shoemaking, Holiday Making, and the Politics of Memory in Early Modern England," Renaissance Quarterly 54 (200I): I,467-94. 


\section{Eighteenth-Century Life}

24. Bob Bushaway, By Rite: Custom, Ceremony, and Community in England, I700-I880 (London: Junction, I982), 45-46.

25. Iorwerth Prothero, Artisans and Politics in Nineteenth-Century London: John Gast and His Times (London: Methuen, 1981), 33-36.

26. See E. P. Thompson, Customs in Common: Studies in Traditional Popular Culture (New York: New Press, 1993), 35-42, 49-83.

27. Anna Clark, The Struggle for the Breeches: Gender and the Making of the British Working Class (Berkeley: Univ. of California, 1995), 67-84, I22-26.

28. The Shoemaker's Glory: or, The Princely History of the Gentle Craft (Newcastle: J. White, [I720?]), , .

29. See Chapman, "Whose Saint Crispin's Day Is It?," I,482-88; William Shakespeare, King Henry V, ed. Andrew Gurr, 2nd ed. (Cambridge: Cambridge Univ., 2005), I75.

30. Angela McShane, "Ne Sutor Ultra Crepidam': Political Cobblers and Broadside Ballads in Late Seventeenth-Century England," in Ballads and Broadsides in Britain, ed. Patricia Fumerton and Anita Guerrini (Farnham: Ashgate, 2010), $216-17$.

31. The Gentle Craft's Complaint: or, The Jolly Shoe-makers humble Petition to the Queen and Parliament (London, [I7Io?]).

32. The Cobler's End, Madden Ballad Collection, Cambridge University Library 4.322 .

33. The History of the King and the Cobler: Part the First (London, [I740-I770?]), 20, 22. On the theme of the disguised king in popular literature, see Burke, Popular Culture, 152-53, and Linda Hutjens, "The Disguised King in Early English Ballads," in Literature and Popular Culture in Early Modern England, ed. Matthew Dimmock and Andrew Hadfield (Farnham: Ashgate, 2009), 75-89.

34. See John Brewer, Party Ideology and Party Politics at the Accession of George III (Cambridge: Cambridge Univ., 1976), I7I-74, I82-91, and Kathleen Wilson, The Sense of the People: Politics, Culture, and Imperialism in England, $1715-1785$ (Cambridge: Cambridge Univ., 1998), 228-36.

35. A New Song (I769?), quoted in Eighteenth-Century Popular Culture: A Selection, ed. John Mullan and Christopher Reid (Oxford: Oxford Univ., 2000), 270.

36. Theophilus Hogarth, Liberty in the Suds; or, Modern Characters (London:

W. Nicholl, I764), I2-I3.

37. John Brewer, "Commercialization and Politics," in Neil McKendrick, John Brewer, and J. H. Plumb, The Birth of a Consumer Society: The Commercialization of Eighteenth-Century England (Bloomington: Indiana Univ., I982), 235, 240, 26I.

38. Naz, The Cobler's Politics: A Country Dialogue, on the Present Times (Manchester: J. Haslingden, [I775?]), 6.

39. John Brown, A Dissertation on the Rise, Union, and Power, the Progressions, Separations, and Corruptions, of Poetry and Music (London: L. David and C. Reymers, I763), I40-54.

40. See Peter Denney, “The Sounds of Population Fail': Changing Perceptions of Rural Poverty and Plebeian Noise in Eighteenth-Century Britain," in Experiences 


\section{Eighteenth-Century Life}

of Poverty in Late Medieval and Early Modern England and France (Farnham: Ashgate, 2012), 299-303.

4I. John Wesley, Free Thoughts on the Present State of Public Affairs (I768), in Political Writings of John Wesley, ed. Graham Maddox (Bristol: Thoemmes, 1998), I38-39.

42. For Wesley's political views, see Bernard Semmel, The Methodist Revolution (London: Heinemann, 1974), chapter 3, and David Hempton, Methodism and Politics in British Society, I750-I850 (London: Hutchinson, I984), chapter 2.

43. William Cowper, The Task (1785), in Poetical Works, ed. H. S. Milford, $4^{\text {th }}$ ed. (London: Oxford Univ., I934), I90, 192-93.

44. James Hurdis, The Favourite Village (I80o) (London: C. Whittingham, I8Io), I7.

45. See M. G. Jones, Hannah More (Cambridge: Cambridge Univ., I952), I325o; Anne Stott, Hannah More: The First Victorian (Oxford: Oxford Univ., 2003), chapter 8; and John Barrell, The Spirit of Despotism: Invasions of Privacy in the I79os (Oxford: Oxford Univ., 2006), 210-44.

46. For this series, see Ronald Paulson, Hogarth: His Life, Art, and Times, 2 vols. (New Haven: Yale Univ., 1971), 2:61-74, and Sean Shesgreen, "Hogarth's Industry and Idleness: A Reading," Eighteenth-Century Studies 9 (1976): 569-98.

47. Hannah More, The Two Shoemakers (London: J. Evans, I795), 8.

48. See Susan Pederson, "Hannah More Meets Simple Simon: Tracts, Chapbooks, and Popular Literature in Late Eighteenth-Century England," Journal of British Studies 25 (1986): 84-II3, especially Io6-08.

49. For the populist orientation of radical parody in the I79os, see Marcus Wood, Radical Satire and Print Culture, I790-I822 (Oxford: Clarendon, I994), chapter 2.

50. Daniel Isaac Eaton, Politics for the People; or, A Salgamundy for Swine, $4^{\text {th }}$ ed., 3 vols. (London: D. I. Eaton, I794), r:I3.

5I. For the political affiliations of Wolcot (Peter Pindar), see Grzegorz Sinko, John Wolcot and His School: A Chapter from the History of English Satire (Wrocław: Prace Wrocławskiego Towarzystwa Naukowego, I962), chapter 4.

52. Peter Pindar, Odes of Importance (London: H. D. Symonds, I792), 3.

53. See the classic studies by Iain McCalman, Radical Underworld: Prophets, Revolutionaries, and Pornographers in London, I795-I840 (1988; Oxford: Clarendon, 1998), chapter I, and David Worrall, Radical Culture: Discourse, Resistance, and Surveillance, I790-I820 (London: Harvester Wheatsheaf, I992), chapter I.

54. Thomas Spence, "A Fragment of an Ancient Prophecy" (I796), in The Political Works of Thomas Spence, ed. H. T. Dickinson (Newcastle Upon Tyne: Avero, I982), 46 .

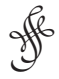

